\title{
PELATIHAN DAN PENDAMPINGAN PENYUSUNAN RPJMDesa BERBASIS PARTISIPATIF DI DESA LOKASARI, SIDEMEN, KARANGASEM, BALI
}

\author{
Bandiyah ${ }^{1}$
}

\begin{abstract}
Abstrak: Kegiatan pelatihan penyusunan RPJMDesa bertujuan memberikan kemudahan dalam penulisan, teknik perencanaan serta pemecahan analitis atas permasalahan pembangunan yang dihadapi desa, khususnya desa yang mengalami ketertinggalan seperti Desa Lokasari Kecamatan Sidemen Karangasem. Di samping itu membantu meringankan tugas pemerintah pusat dan daerah dalam rangka menghasilkan output RPJMDesa yang bermutu dan tepat sasaran. Metode kegiatan yang digunakan adalah dalam bentuk pelatihan dan pendampingan dengan mengacu pada analisis alternatif rencana dan tindak pemecahan masalah pada masingmasing bidang di satuan desa dengan basis partisipatif. Hasil output dari kegiatan ini pertama, aparatur desa sangat antusias dalam mempelajari metode penyusunan RPJMDesa karena dianggap sebagai pengetahuan baru. Kedua, metode ini mudah disusun dan diaplikasikan dalam RPJMDesa. Ketiga, aparatur desa dan masyarakat menambah wawasan pengetahuan dan bahasa ilmiah yang belum diketahui sebelumnya. Outcame kegiatan adalah menjadi motor penggerak dan konsultan pendamping bagi desa-desa yang belum mandiri.
\end{abstract}

Kata Kunci: Partisipatif, RPJMDesa, Pelatihan, Pendampingan.

\section{The Training and Assistance of RPJMDesa Preparation with Participatory-based at Lokasari Village, Sidemen, Karangasem, Bali}

\begin{abstract}
RPJMDesa preparation training activities aimed at providing convenience in writing, analytical planning techniques and solutions to the problems faced by rural development, in particular villages are lagging as Lokasari village of Sidemen subdistrict, Karangasem. In addition, to help ease the task of national and local governments in order to generate output RPJMDesa quality and right on target. Activity methods used are in the form of training and guidance by referring to the analysis of alternatif plans and follow the trouble shooting on each field in the village unit with a participatory basis. The output of this activity first, village officials are very enthusiastic in learning the methods of preparation RPJMDesa being perceived as the new knowledge. Second, this method is easily prepared and applied in RPJMDesa. Third, village officials and community broaden the knowledge and scientific language that has not been previously known. Outcome activity is becoming a driving force and assisting consultants for villages that have not been independently.
\end{abstract}

Keywords: Assistance, Participatory, RPJMDesa, Training.

\section{PENDAHULUAN}

Sejak tahun 2005, sistem perencanaan pembangunan daerah di Indonesia mengalami perubahan yang cukup mendasar. Perubahan ini terjadi karena mulai diterapkannya otonomi daerah dalam system pemerintahan dimana pemerintah daerah termasuk pemerintah desa diberikan sumber keuangan dan kewenangan lebih besar dalam merencanakan dan melaksanakan pembangunan di daerahnya masing-masing. Ditambah lagi sejak diterbitkannya UU no 6 tahun 2014 kemudian disusul Peraturan

\footnotetext{
${ }^{1}$ Program Studi Ilmu Politik, Universitas Udayana, Denpasar; email: dyah_3981@yahoo.co.id.
} 
Pemerintah no 47 tahun 2015 tentang pemerintahan desa mengamanatkan bahwa pemerataan pembangunan harus dimulai dari desa.

Untuk mewujudkan pembangunan tersebut pemerintah pusat memberikan dana desa yang sangat pantastik dengan masing-masing desa mendapatkan kurang lebih 1,4 milyar rupiah. Dana desa ini dapat dikelola dengan baik dan akuntabel apabila perencanaan pembangunan desa telah dibuat dengan benar dan tepat sasaran yang terbungkus dalam dokumen RPJMDesa. Penyusunan RPJMDesa berpedoman pada RPJMD (Rencana Pembangunan Jangka Menengah Daerah). Namun demikian, tidak semua aparatur desa dapat membuat RPJMDesa dengan baik sesuai dengan kebutuhan, meskipun terdapat panduan teknis dari RPJMN (Rencana Pembangunan Jangka Menengah Nasional) yang dimotori oleh Bapennas.

Rencana Pembangunan Jangka Menengah Desa (RPJMDesa) merupakan salah satu dokumen perencanaan pembangunan yang penyusunan diwajibkan kepada setiap pemerintahan di tingkat desa. Pembuatan RPJMD ini biasanya dilakukan dalam periode lima tahunan setelah pelantikan kepala daerah untuk tingkat kota kabupaten dan propinsi, dan kepala desa untuk tingkat wilayah desa. Dalam RPJMD bersifat lebih operasional, namun untuk mewujudkan perencanaan yang terpadu baik di tingkat nasional, maupun di masing-masing daerah dan desa harus diawali dari sebuah pemilihan kepala daerah ataupun desa. Pemilihan kepala daerah secara serentak telah dilaksanakan Bangsa Indonesia pada Desember tahun 2015 lalu. Cara pemilihan seperti ini setidaknya akan membuat masa tugas dan jadwal waktu perencanaan pada RPJM menjadi sama dan terukur. Inilah sebenarnya yang dibutuhkan agar perencanaaan pembangunan Indonesia terintegrasi secara nasional dari tingkat pusat, lokal daerah hingga tingkat desa.

Hasil sebuah perencanaan dapat diterima dengan baik oleh masyarakat setempat apabila dalam penyusunannya melibatkan partisipasi dari masyarakat. Tanpa partisipasi, biasanya hasil perencanaan berakibat pada kekecewaan karena tidak sesuai dengan keinginan dan harapan dari masyarakat. Di samping itu, akan sulit mengharapkan masyarakat untuk mematuhi dan menjaga pelaksanaan kegiatan yang telah dibuat sebelumnya. Bahkan tidak jarang pula terjadi, masyarakat tidak memanfaatkan sepenuhnya apa yang telah dibangun oleh pemerintah desa. Oleh karena itu sangat tepat kiranya bilamana dalam pembuatan RPJMDesa melibatkan partisipasi masyarakat dalam menentukan perencanaan pembangunan desa.

Menurut Syafrizal (2014: 30) terdapat cara yang bisa dimanfaatkan untuk membangun partisipasi yaitu dengan melakukan jaringan aspirasi masyarakat (Jaringan Asmara) dalam bentuk pertemuan, diskusi, dan seminar guna mendapatkan pandangan masyarakat tentang visi dan misi pembangunan yang diinginkan. Aspirasi masyarakat sebenarnya dapat juga dilakukan atau diserap pada saat pelaksanaan MUSREMBANG Desa yang telah diamanatkan dalam Undang-Undang no 25 tahun 2004. 
Permasalahannya kini, bahwa penyusunan RPJMDesa tidaklah mudah melainkan dibutuhkan perhatian khusus berupa kemampuan pengetahuan dan keterampilan tentang perencanaan pembangunan serta kepekaan terhadap kondisi desa yang ditinggalinya. Pada umumnya banyak ditemukan desa-desa di wilayah Indonesia bahwa aparatur desa mulai dari kepala desa, sekretaris desa dan jajarannya tidak semua berasal dari masyarakat kelas menengah berpendidikan tinggi, memiliki banyak pengalaman dan teori dalam bidang perencanaan. Oleh karenanya penyusunan RPJMDesa diperlukan pelatihan dan pendampingan khususnya bagi Desa Lokasari Sidemen Karangasem yang memiliki keterbatasan sumber daya manusia (SDM), kurang pengetahuan dan keterampilan penyusunan RPJMDesa, fasilitas sarana prasarana desa tidak memadai, serta letak geografis yang tidak menunjang.

Berdasarkan analisis situasi yang diuraikan di atas, perlu kiranya institusi akademisi yang memilki kemampuan pada metode perencanaan pembangunan untuk membagikan dan transfer ilmu serta keahlian melalui pelatihan dan pendampingan dalam rangka ikut serta membantu tugas pemerintah pusat dan daerah dan masyarakat desa untuk menguatkan pelaksanaan otonomi desa melalui pelatihan penyusunan RPJMDesa.

\section{METODE PELAKSANAAN}

Metode yang digunakan dalam kegiatan ini berupa pelatihan dan pendampingan kepada aparatur desa untuk menyusun RPJMDesa di Desa Lokasari Kecamatan Sidemen Karangasem Bali. Aparatur desa terdiri dari Kepala desa, Sekretaris desa, ketua LPD, LPM, kepala bidang dan staf desa (bidang penyelenggaraan pemerintah, bidang pelaksanaan pembangunan, bidang pembinaan masyarakat, dan bidang pemberdayaan masyarakat), kelian banjar, kelian dinas, dan tokoh masyarakat. Tahap pertama kegiatan adalah melakukan survei desa dan audiensi persiapan pelaksanaan pelatihan dengan menjaring aspirasi dari berbagai pihak baik dari kepala desa, sekretaris desa, ketua LPM, LPD, dan perwakilan dari tokoh masyarakat yang memiliki pengaruh pada masyarakat desa. hasil audiensi untuk mendapatkan gambaran dan pemetaan masalah desa kemudian ditentukan metode yang tepat untuk pelatihan di kemudian hari. Tahap kedua adalah menjelaskan materi RPJMDesa dengan menggunakan teknik analisis, metodelogi dan indikator pemecahan masalah yang mudah dipahami dan diimplementasikan oleh tim penyusun RPJMDesa. Pemberian materi diikuti dengan diskusi tanya jawab dan mengakomodir semua input dari peserta. Tahap selanjutnya adalah pelatihan dan penulisan penyusunan RPJMDesa oleh masing-masing bidang yang sudah ditentukan oleh desa. Dalam hal ini ada empat bidang yaitu 1). Bidang Penyelenggaraan Pemerintah Desa, 2). Bidang Pemberdayaan Desa, 3). Bidang Pembinaan Desa, 4). Bidang Pembangunan Desa). kegiatan ini disertai pendampingan dan konsultasi. Penyusunan RPJMDesa ini ditulis berdasarkan kondisi pembangunan desa secara real, bukan imajinatif.

Kegiatan pelatihan ini dilaksanakan dalam waktu lima jam (pkl. 09.0014.00 wita). Penyusunan RPJMDesa bukanlah sesuatu yang mudah, 
dibutuhkan analisis data dan informasi real sesuai dengan kondisi desa sebenarnya. Oleh karenanya sebelum pelatihan, peserta sudah menyiapkan data dan informasi di bidangnya masing-masing. sehingga pada saat pelatihan tinggal didiskusikan mengenai permaslahan apa yang menjadi prioritas diajukan dalam draf RPJMDesa. Setelah penyusunan poin-poin draf RPJMDesa, hasilnya dipresentasikan di depan forum selama 15 menit ( 5 menit presentasi dan 10 menit tanya jawab) dengan harapan tim pengabdian FISIP UNUD dapat memberikan masukan dan arahan dari hasil kegiatan pelatihan. Di akhir kegiatan dilakukan evaluasi hasil pembelajaran pelatihan penyusunan draf RPJMDesa yang sudah dikerjakan oleh masing-masing bidang desa. Kegiatan pengabdian dilaksanakan di kantor kepala desa, ruangan pertemuan Desa Lokasari Kecamatan Sidemen dengan didampingi oleh beberapa dosen dan dibantu oleh mahasiswa FISIP Universitas Udayana, Bali.

\section{HASIL DAN PEMBAHASAN}

Pelaksanaan kegiatan pengabdian masyarakat dalam bentuk pendampingan dan pelatihan RPJMDesa dilaksanakan pada hari Rabu, 25 Agustus 2016 di Desa Lokasari Sidemen Karangasem. Kegiatan ini dihadiri oleh 25 orang peserta yang terdiri dari Kepala desa, sekretaris desa, ketua LPM, ketua LPD, staf aparatur desa, kepala bidang dan tim penyusunan RPJMDesa, kelian adat, kelian banjar, perwakilan PKK, Tokoh masyarakat, tim dosen FISIP Unud dan juga mahasiswa.

Kegiatan pengabdian masyarakat yang diimplementasikan oleh Program Studi IImu Politik Fakultas IImu Sosial dan IImu Politik Universitas Udayana direspon sangat baik oleh kepala desa, staf aparatur desa dan juga masyarakat Desa Lokasari. Kondisi desa dengan SDM terbatas membutuhkan transformasi pengetahuan dan keterampilan dalam rangka memperbaiki kinerja pemerintahan desa untuk menghasilkan produk RPJMDesa berkualitas. Alasan yang lain adalah: pertama, Kepala Desa Lokasari yang baru dilantik Bulan Juli 2016 lalu dianggap minim pengalaman, kurang pengetahuan dan skill pengelolaan pemerintahan desa terutama dalam menyusun rancangan pembangunan desa (RPJMdesa). Kedua, Desa Lokasari tidak memiliki banyak potensi desa yang dapat menyumbangkan (PAD) pendapatan asli desa. Potensi desa hanya bersumber dari hasil pertanian dan perkebunan dan hasilnya tidak mencukupi ekonomi masyarakat. Ketiga, sarana dan prasarana seperti fasilitas kantor desa tidak memadai, rusak kumuh, dan sempit. kondisi tersebut dapat menghambat pelaksanaan roda pemerintahan desa. Keempat, pemahaman aparatur desa yang minim terhadap teknik analisis penyusunan RPJMDesa untuk menentukan sasaran obyek dan mampu menyelesaikan permasalahan desa.

Sebenarnya aparatur Desa Lokasari sudah sangat familiar dengan RPJMDesa, sebab setiap lima tahun sekali kegiatan ini dilakukan. Namun demikian sering mengalami kesulitan dalam memformulasikan permasalahan desa yang begitu banyak dan harus diinput dalam RPJMDesa disamping sumber informasi dan data yang juga terbatas. Sebagai contoh aparatur desa 
kesulitan menentukan kategori miskin karena perbedaan data dan informasi yang tidak jelas terhadap sumber yang akan dipakai. Selain itu, penggunaan metodologi sebagai cara menentukan informasi dan mengolah data kurang diperhatikan sehingga aparatur desa belum bisa menentukan permasalahan dengan skala prioritas. Yang terjadi adalah perdebatan kusir di ruang rapat yang tidak pernah selesai terjawab.

Oleh karena itu, beberapa keluhan dan pertanyaan peserta yang muncul telah dikemas dengan materi pelatihan yang lebih mengedepankan tindakan konsultatif, penyediaan ruang partisipatif, dan melakukan analitis alternatif dalam pemecahan tindakan yang dilakukan pada masing-masing bidang kerja perumusan RPJMDesa yang sudah ditentukan. Pemberian materi dilakukan secara singkat, agar peserta lebih fokus pada pelatihan penulisan draf RPJMdesa. Peserta dibagi kelompok berdasarkan bidang kerjanya masingmasing, setiap bidang, misalnya bidang pelaksanaan pembangunan desa menuliskan dan menginput permasalahan pokok di bidang tersebut, mencari penyebab, menggali potensi desa yang dapat meminimalisir persoalan, setelah itu menentukan bagaimana alternatif tindakan yang layak untuk mengatasi persoalan dalam bidang masing-masing.

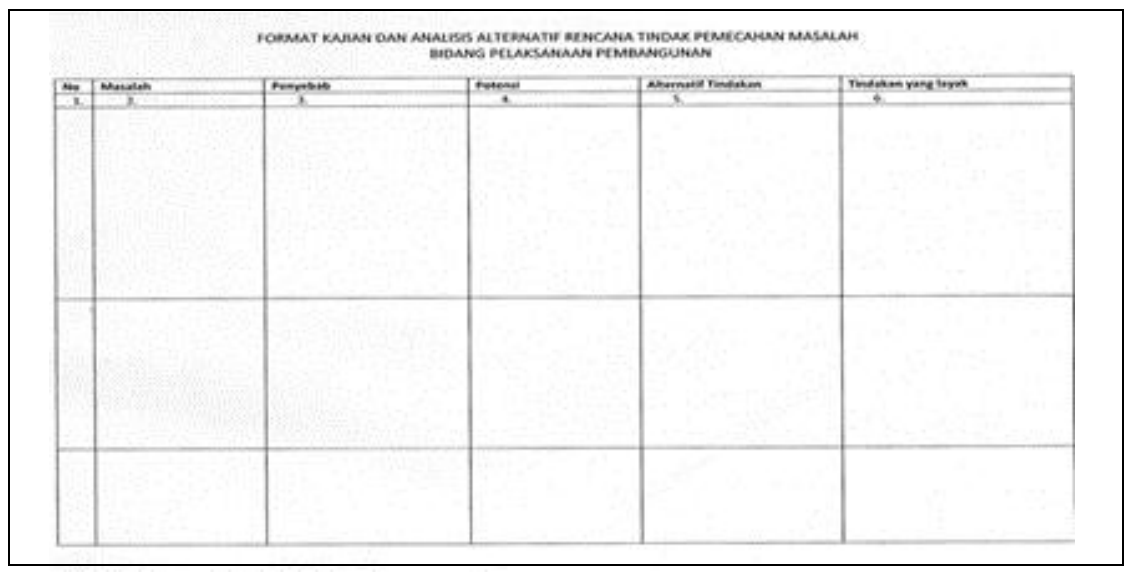

Gambar 1. Bentuk Format Kajian dan Analisis Alternatif Rencana Tindak Pemecahan Masalah Setiap Bidang Kerja

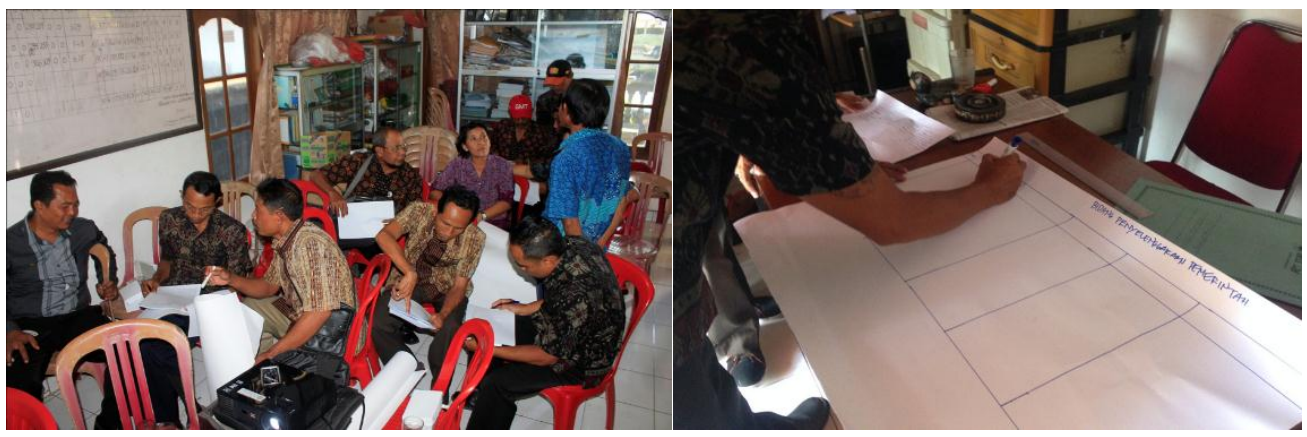

Gambar 2. Antusias Peserta dalam Mengikuti Pelatihan Penyusunan RPJMDesa 
Pada saat pendampingan penyusunan draf RPJMDesa, banyak diantara aparatur desa yang tidak mengerti makna kata-kata yang tertulis di setiap format kajian. Hal ini dikarenakan aparatur desa belum familiar menggunakan format tersebut. Oleh karena itu sering terjadi kebingungan misalnya dalam mencari potensi desa dan bagaimana alternatif tindakannya. Meskipun sebenarnya format ini terbilang mudah untuk diaplikasikan, yang diperlukan adalah analisis data yang akurat untuk memudahkan input penulisan dan latihan secara berkesinambungan. Dengan keterbatasan aparatur Desa Lokasari, metode ini diberikan paling tidak sebagai pengenalan terutama bagi tim penyusun RPJMDesa agar dapat memahami butir-butir penting yang harus diperhatikan dan di-input dalam menyusun RPJMDesa. Banyak di antara aparatur desa yang antusias menanyakan dan berkonsultasi terkait permasalahan di bidangnya. Selama ini di Desa Lokasari belum pernah ada kegiatan yang memberikan ruang konsultasi dan pendampingan intensif dalam merumuskan program desa. Bahkan di akhir kegiatan ini ketua LPM dan kepala desa meminta dampingan lanjutan untuk membimbing dan mengevaluasi hasil kerja mereka dalam menyusun draf RPJMDesa pada implementasi nyata di kemudian hari.

Meskipun pemerintah pusat telah menyediakan tenaga pendamping desa di semua wilayah kabupaten dan kota di Indonesia yang diseleksi secara ketat, namun dalam aplikasinya di lapangan banyak ditemukan pendamping desa yang tidak berfungsi dan bekerja maksimal dalam mendampingi desa, sehingga masih ditemukan desa yang masih tertinggal dalam informasi, teknologi dan pembangunan lainnya seperti terjadi di Desa Lokasari, Sidemen. Terdapat beberapa temuan pendamping desa yaitu: pertama, karakter pendamping desa yang individual dan tertutup, kurang bersosialisasi dengan masyarakat. Kedua, pengetahuan minim dari pendamping desa terkait dengan kondisi dan ruang lingkup desa, sehingga pendamping desa tidak bisa bekerjasama dalam membangun desa, alhasil pekerjaan pemerintah ini terkesan sia-sia.

Tenaga pendamping desa tidak hanya didasarkan pada modal intelektualitas, tetapi juga mesti memiliki keterikatan jiwa sosial dengan desa. Sehingga transfer ilmu dari kaum intelektualitas dapat mudah disampaikan kepada aparatur desa dan masyarakat.

\section{KESIMPULAN}

Kegiatan pelatihan dan pendampingan adalah salah satu kegiatan pengabdian kepada masyarakat yang diperlukan oleh masyarakat desa yang belum berdikari. Metode analitis terhadap tindak pemecahan masalah adalah metode sederhana yang dapat diterapkan dengan mudah oleh masing-masing bidang pemerintahan desa untuk membuat draf RPJMDesa. Kebiasaan bisa dimulai dengan melakukan latihan-latihan penyusunan draf tersebut hingga menjadi sebuah keahlian memadai. Persoalan desa memerlukan perhatian semua pihak dan bantuan kerjasama antara beberapa elemen, baik dari 
institusi pemerintah daerah, akademisi, swasta, maupun masyarakat agar otonomi desa segera terwujud.

\section{REFERENSI}

Pemerintah Negara Republik Indonesia (2015). Peraturan Pemerintah Nomor 47 Tahun 2015. Jakarta.

Republik Indonesia. (2014). Undang-Undang Nomor 6 Tahun 2014 Tentang Desa. Jakarta.

Ritonga, I. T. (2009). Perencanaan dan penganggaran keuangan daerah di Indonesia. Sekolah Pascasarjana UGM.

Sjafrizal. (2014). Perencanaan pembangunan daerah dalam era otonomi. Jakarta: Raja Grafindo Persada. 